\title{
Causes and Precautions of Financial Risks of Commercial Banks in China
}

\author{
Ran Liu \\ College of Economic Management, Dalian University \\ Dalian, China \\ laurenred@sina.com
}

\begin{abstract}
Commercial banks are the pillar industry in financial industry. As an important part of economic development, it plays an intermediary role in improving social capital and has a very important social status. However, with the full integration of China's commercial banks and world's financial industry, the Chinese commercial banks are facing development opportunities as well as a certain degree of risk pressures. In this paper, the financial risk of commercial banks is analyzed from the original credit risk and market risk based on the provisions of the new Basel agreement. The importance of strengthening financial risk prevention is demonstrated from the characteristics and hazards of these three kinds of risks. The paper analyzes the causes of financial risks of commercial banks from the perspectives of macro-environment, internal control and capital structure, and proposes some suggestions for commercial banks to adapt to macro environment and to attach importance to talents and improve capital structure.
\end{abstract}

Keywords-Commercial bank; financial risk; Bank internal control; Financial risk prevention; Capital structure

\section{INTRODUCTION}

In recent years, the frequently occurred economic crisis has brought a great influence on the financial industry, especially the banks. The western countries focus on the innovation of commercial banks but neglect the financial risks. The financial market has opened up and developed rapidly since China's accession to the WTO. The banking industry faces the development opportunity as well as huge competition and challenges. How to do well the financial management of banks has become the focus of China's banking industry at present. The prevention of bank financial risk is the most important part of bank financial management [1,2]. Commercial banks are among the major financial intermediaries in the marketplace. Commercial banks are exposed to the risks that affect both the securities markets and the economic conditions that affect consumers. To understand the risks associated with commercial banks, it is helpful to consider some key areas that affect banking operations.

Some progress on the risk of the commercial banks has been made. The new Basel Agreement consists of three important aspects, viz., the minimum capital requirement, the regulatory authorities' supervision and inspection of capital adequacy ratio (external regulation), and the information disclosure requirements of banking industry [3, 4]. In February 28, 2007, China Banking Regulatory Commission issued the guiding opinions on the implementation of the new capital accord in China's banking sector, marking the start of the implementation of the new Basel Capital Accord project in China[5]. The financial environment in China does not have mature conditions for the implementation of the agreement, and the prevention and research of financial risk is also lagging behind the Western countries. China is gradually deepening and increasing the system reform in the market economy, so that China is facing more uncertainty in the development of the national economy. Thus, the financial management risk of commercial banks in China is gradually increasing. The capital adequacy ratio of commercial bank in China is generally higher than the minimum standard of $8 \%$. However, the capital structure is still not ideal. The rate of non-performing assets is high and even increasing year by year. This is an important financial risk for banks. There are many reasons for the financial risks of commercial banks, and new contradictions have emerged in the old contradictions, such as the increase of the capital adequacy ratio. Therefore, it is of great significance to analyze the reasons for financial risk of banks and how to prevent it in China.

\section{FINANCIAL RISK THEORY OF COMMERCIAL BANKS}

\section{A. Financial Risk of Commercial Banks}

The financial risk of commercial banks in a narrow sense refers to the risk that the commercial banks need to bear the loss due to the irrational financial structure. The financial risk of commercial banks in a broad sense is influenced by all kinds of unpredictable or control factors. The risk that the financial situation is uncertain and mainly manifested in the financial loss of the bank.

\section{B. Classification and Characteristics of Financial Risk}

The early credit risk mainly refers to the bank's credit risk. However, in the past, financial products are increasingly diversified and emerging markets have flourished, and financial product transactions are becoming more and more complex. The credit risk is no longer limited to the traditional banking business, and its meaning has also changed accordingly [6]. At present, the definition of credit risk is widely used, which is the possibility that banks cannot be able to repay all or part of the sum of money with commercial banks' transactions. It is of great practical significance to the avoidance and management of the financial risk of the bank. High credit risk is a major challenge for the operation and operation of commercial banks in China. In the banking business, the loan is a major asset business, requiring the bank to make a judgment on the borrower's credit level. But because 
of information asymmetry, these judgments are not always correct, and the borrower's credit level may fall for a variety of reasons. Therefore, the main risk that banks face is the risk that banks cannot perform their performance as scheduled. There are four characteristics of credit risk [7]: 1) objectivity. The existence of credit risk is objective. 2) Contagious. The difficulty or bankruptcy of one or a few credit subjects will lead to the disorder of the credit chain and the whole credit order. 3) Controllability. The existence and occurrence of credit risk is not changed, but it can be reduced by commercial banks. The bank can carefully handle the loan business by improving the recognition ability of the borrower's credit status. 4) Periodicity. It shows that credit expansion and contraction occur alternately.

Market risk refers to the risk of unanticipated potential losses due to changes in the stock market price, interest rate, exchange rate, etc. Market risks include equity risk, exchange rate risk, interest rate risk and commodity risk. At present, commercial banks are influenced by external economic policies and the increasingly frequent changes in industrial environment The operation and development strategies of commercial banks are also being followed up and adjusted in a timely manner. The survival mode of "survival of the fittest" is more incisively and vividly embodied in the financial industry[8]. Although market risk cannot be directly reflected in the financial risk of commercial banks, market risk will directly affect the components of financial risk. Thus, the financial risks of commercial banks have a great influence. The current financial environment in China is becoming more and more open. Commercial banks must have a more scientific and accurate judgment of their external market environment to effectively avoid and prevent financial risks in the business process.

The operational risk was first put forward by the British Bankers Association in 1997. It believes that operational risk is associated with human error, incomplete procedural control, fraud and criminal activity. It is caused by technical defects and system collapse. The new Basel agreement defines operational risks as risks caused by imperfect or problematic internal procedures, personnel, and system or external events. Operational risk is also a part of the new Basel protocol's new risk management framework. The occurrence of operational risk is later than credit risk and market risk. The collapse of the Bank of Bahrain, the big and the banks in 1990s was caused by operational risks. In 2014, a total of 75 operational risk cases involve over a million yuan in China's commercial banks, including 6 from the people's bank, 15 from the Agricultural Bank, 17 from the Construction Bank, 18 from the Bank of China, and 10 from other financial institutions. In addition to the 13 cases of unknown amount, other cases caused the loss of state-owned assets up to 2 billion 415 million yuan. Operational risk has become an important risk in the business process of commercial banks [9].

Compared with credit risk and market risk, there are obvious characteristics: first, the risk in operational risk mostly comes from the bank's business operation, and belongs to the endogenous risk that the bank can control. Credit risk and market risk are more of an exogenous risk. The second is the different coverage of operational risk. It is actually almost the bank management of the different risks in all aspects of management. It not only includes the small mistakes of the daily business process, but also the natural disasters and largescale losses that endanger the bank's survival.

\section{Prevention of Financial Risk}

The risk is objective. Therefore, we should strengthen the management of financial risk in the related aspects and actively prevent the sudden risk of risk. Moreover, the corresponding measures should be taken to reduce the financial risk of the bank to the greatest extent.

\section{CAUSES OF FINANCIAL RISK OF COMMERCIAL BANKS}

\section{A. Immature Macro Development Environment of Banks}

Compared with in western countries, the development of market economy in China is relatively late. The macro environment of commercial banks is not mature enough. China's financial market is in the transition period of further adjustment of the economic and financial system. At the same time, the market access standards need to be further improved. The imperfect financial environment causes the unlawful events in the commercial banks to occur frequently. In addition, the supervision and efficiency of various aspects are not ideal because of the imperfect market management model. Most of the supervision of the banking industry is after the post management, the lack of pre-prevention will bring greater financial risk to the commercial banks. In the face of perplexing domestic and international economic and financial situation, Chinese government insists on maintaining stability in the general work guideline. The economic operation of China is kept in a reasonable range, and the annual GDP growth is $6.9 \%$. In 2016, the global economy will continue to continue to adjust in depth and continue to show an uneven recovery. The downward pressure of China's economic downturn is still large, and the economic operation is still facing certain uncertainties and risks. As the pillar industry of the financial industry, the bank is greatly influenced by the economic conditions. The bank's bad loan rate is likely to rise as the economy is sluggish.

The excessive pursuit of profit in the banking industry has caused fierce competition among banks. Some banking institutions regard non-standard and unfair competition as a means to expand business scale and increase market share. In recent years, the increase of RMB exchange rate has brought great benefits in promoting the competitiveness of China's banks and attracting foreign exchange influx. But it also causes the devaluation of the bank's foreign exchange assets, which further increases the difficulty of the bank's asset management. Some local banks may not be able to strictly enforce the process of bank approval to expand the size of their loans.

In addition, the new vitality of the financial industry, the Internet finance also to a certain extent, robbed commercial banks. Internet finance has a great impact on the traditional banks. However, it must be clear that the impact of the impact on banks is also conducive to the healthy and orderly development of the banks. If there is no impact and influence of the Internet, to state-owned enterprises as the representative of the traditional banking sector will continue to progress. 
However, commercial banks have encountered a series of problems in the process of operation, such as the decline of profits and the increase of non-performing loans. Bank managers tend not to blame their own reflection on their responsibilities to the business and the Internet. Commercial banks generally believe that the decline in credit of real enterprises has led to a rise in the rate of non-performing loans in the banks. The decline in profits is the impact of Internet finance, and the increase in risk is attributed to excessive government intervention. Commercial banks can correctly view their relationship with Internet finance and make full use of the technical advantages of the Internet to carry out diversified funds.

At present, commercial banks are faced with problems such as single operating means and rigid operating mode. The commercial banks are unable to adapt to the trend at present. The banks in the economically developed areas are obviously superior to the commercial banks in the less developed areas in terms of bank scale, capital turnover capacity and personnel service ability. The service structure of commercial banks in some country is still single and the technical equipment is backward, which cannot meet the needs of all levels. The current business is mainly limited to traditional credit, narrow channel of settlement, low electronic level, and single service and service. It is difficult to meet the growing demand for funds. In the multilevel, multifield and multi- type development process of the rural economy, the process of development is obviously lagging behind. In such a backward financial management mode and business environment, business operation of the bank is easy to its loopholes appeared one after another. Thus, the financial risk of the bank is controlled at a lower level.

\section{B. Financial Personnel with Weak Risk Awareness and Lower Professionalism}

With the expansion of the bank's new business, there is a serious shortage of talents who are truly proficient in financial management. Financial managers cannot understand and manage financial risks from the financial activities. They usually believe that if they manage well the funds, there will be no financial risk. With the development of financial products and the expansion of banking business, the existing bank financial personnel can no longer meet the needs of new businesses. People who are proficient in financial risk management are seriously inadequate. Many financial personnel cannot accurately identify the trustworthiness of borrowers, deteriorate the quality of bank assets, and cause the rate of non-performing loans to rise. The lack of talent will directly affect the quality and consequences of a series of activities, such as business expansion, internal management, risk prevention, and so on.
China's commercial banks are facing the general problems of banking industry. Most banks still take the precaution of credit risk as the leading factor, often ignoring the management risk in the market. In the operation, the control of its risk still pays attention to the internal control stage, and it has not yet formed the operation risk control in the form of measurement. At present, China's commercial banks still experience a lack of awareness in financial management, low scientific management level.

\section{Unbalanced Capital Structure}

The capital structure of a commercial bank is a proportion relationship between the debt funds and the private capital of a commercial bank. Capital structure decides not only the cost of financing but also the final value of a bank. Over the past few years, the capital adequacy ratio of China's commercial banks has been greatly improved, which is significantly higher than the minimum $8 \%$ level stipulated in the new Basel agreement, but there are still other aspects of capital structure imbalance.

High capital liability rate and a single debt capital structure. The bank is a debt management enterprise, and the debt is an important source of capital for the bank's operation. The size of liabilities affects the amount of profits, and quality is the guarantee of liquidity and security. Therefore, we need to effectively arrange all kinds of liabilities and form an efficient and stable debt system. In 2015 affected by the economic slowdown, the interest rate market reform, financial disintermediation and other factors, the banking industry sources of funds affected. At the end of 2015, the total liabilities of banking financial institutions were 184 trillion and 140 billion yuan, up $15.07 \%$ from the same period. From the point of view of the deposit business, the growth rate has slowed slightly, but the scale of deposit increases steadily, and the asset liability rate remains high. Most of China's commercial banks have higher asset liability ratio, which brings higher income and higher financial risk. On the other hand, the liabilities of commercial banks are mainly deposits.

High rate of non-performing assets. At present, the high rate of non-performing assets of commercial banks, asset quality tends to deteriorate, as can be seen from the chart the high rate of non-performing assets in 2016, the agricultural bank of china $(\mathrm{ABC})$ and Shanghai Pudong development bank (SPDB), China merchants bank (CMB), agricultural bank of China is reached $2.41 \%$, ICBC's non-performing loan ratio reached $1.62 \%$, the provision coverage rate is only 136.69 . The reserve coverage rate of Guiyang commercial banks is sufficient, and the bank reserve pressure of other banks is still relatively large. The non - performing loan rate of the five major commercial banks increased from 2013 to 2016. The higher NPL directly affects the profit of commercial banks and brings high financial risk to the operation of the banks. 
TABLE I. BANK ASSET LIABILITY RATIO STATISTICS IN 2016

\begin{tabular}{lccc}
\hline & Total Assets & Total Liabilities & Ratio \\
\hline Bank of China & $18,148,889,000,000$ & $16,661,797,000,000$ & $91.80 \%$ \\
Bank of Comm. & $8,403,166,000,000$ & $7,770,759,000,000$ & $92.47 \%$ \\
Minsheng Bank & $5,895,877,000,000$ & $5,543,850,000,000$ & $94.03 \%$ \\
China M. Bank & $5,942,311,000,000$ & $5,538,949,000,000$ & $93.21 \%$ \\
CITIC Bank & $5,931,050,000,000$ & $5,546,554,000,000$ & $93.52 \%$ \\
\hline
\end{tabular}

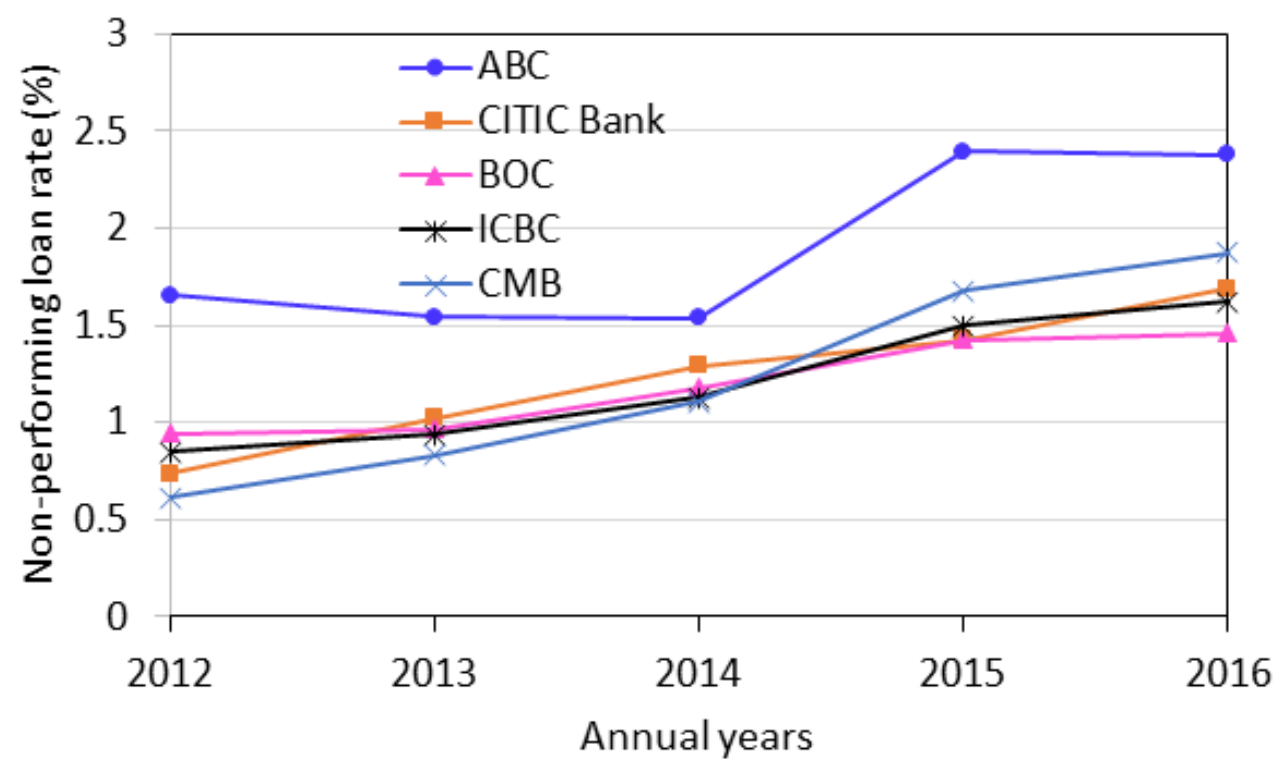

Fig. 1. The non-performing loan rate curves of the commercial banks according to annual report in 2016

\section{High financial Decision Mistakes}

The scientific level of financial decisions in China's commercial banks is relatively low. In the process of financial decision making, there are phenomena of experience decisionmaking and subjective decision making, resulting in frequent failures in decision-making. Policymakers did not carefully collect comprehensive real economic information based on their past experience and subjective judgment to make decisions on investment and projects, resulting in decisionmaking mistakes. Appropriately expanding the scope of bank decision makers, designing decisions for major interests and fund safety of banks cannot be formulated solely by shareholders' meetings and boards, but also allow more input and advice from bank accountants. Financial decisions cannot be confined to the leader and the management of their decision often statements of a school, the group focuses on the overall level of profitability, with subjective judgments, so the decision should benefit by mutual discussion, give full play to the initiative of each department, work together.

\section{PREVENTION AND SUGGESTIONS OF FINANCIAL RISK}

\section{A. Improving the Adaptability to Macro-environment}

High-quality financial management personnel for banks are essential to improve the external economy of banks and change unpredictably market environment adaptability. We should improve the rules and regulations of financial management, make an accurate analysis of the changing external environment, grasp the trend of change, make timely adjustments to the financial management methods and policies, and do well in the prevention and control of risks ahead of schedule. 


\section{B. Improving Capital Structure}

The bank's asset liability ratio is ideally maintained at $50 \%$. Actively responding to this situation, the bank should consider reducing the amount of bank deposits, promote the development of diversified liabilities, diversified liability business, and actively carry out the discount or borrowing from the central bank lending, the issuance of financial bonds, the international money market loans and other services. Facing the high rate of non-performing loans is also a urgent problem for commercial banks. The solution of bad assets and the reduction of risk assets are of great significance for improving the capital structure of commercial banks, preventing financial risks and ensuring financial stability. Assets can be sold to reduce the size of the assets, and the sale of assets can reduce the bad assets actively and flexibly with lower costs and rapid results. In addition, the market level of the disposal of nonperforming assets should also be improved. In order to improve the quality of new loans, commercial banks can achieve it by reducing the amount of loans or increasing the credit review of the lender. Therefore, commercial banks should take the initiative to win new market opportunities, actively use effective marketing methods, expand high-quality customers, strictly grasp the investment of new loans, and increase the business growth means and the optimization of new loans.

\section{Improving Internal Control System of Financial Risk}

Internal control refers to the bank to achieve business objectives, protect asset integrity, guarantee the authenticity and legitimacy of the financial accounting information, and implement the management and decision-making, policy and system, and improve economic benefit and the formation of an internal self-adjustment, restraint and supervision means. Commercial banks should establish and improve the internal control system, formulate a comprehensive, systematic and standardized business system and management system for all business activities and management activities, and conduct periodic assessments. We should rationally define the risk control points of various business activities and management activities, take appropriate control measures, and carry out standard unified business processes and management processes, to ensure standardized operation. The scientific risk management techniques and methods are used to fully identify and evaluate the risks faced in the operation, and to monitor the major risks.

In order to improve the efficiency of bank operation, the accounting department must post analysis direction control, in the past before and after the scores in accounting, accounting change from simple reimbursement type to participate in management, grasp the initiative in work. Only when we have accounting in advance, control in things and analysis afterwards can we avoid blindness in our work and give full play to the role of accounting departments in improving economic efficiency. Commercial banks should focus on the internal audit of the accounting department, which is conducive to the management of financial risks. The bank should strengthen internal accounting control and strengthen the inspection in order to prevent the illegal and unregulated operation of the personnel in the bank.

\section{Improving Quality and Risk Awareness of Staff}

Strengthening the awareness of financial risk. For China's commercial banks generally financial risk awareness is weak, the business of commercial banks is a process from the head to the tail in the game with the risk, so every aspect of financial risk also exists in banking operations, each person, each department will face the risk, risk management. Therefore, we must cover the whole bank with the concept of risk culture, so that every employee has the first consciousness.

High quality financial managers can make sensitive and accurate professional judgments about financial risks and identify and estimate potential financial risks in time. Most banks lack the reasonable control of the financial risk. According to the staff at different levels, the bank should ask for the management respectively. For senior managers, they should cooperate with other business areas and play a coordinating role. Banking institutions should actively promote grassroots risk identification training and enhance financial staff skills training.

\section{E. Improving Decision-Making and Innovation Awareness}

Banks must take full account of various factors that affect decisions, adopt quantitative calculation and analysis methods as much as possible, and make decisions with scientific decision models, and avoid subjective assumptions. The establishment of bank decision support system, with the increasingly fierce competition among the major banks, only the realization of the electronic business of daily business can no longer meet the needs of the development of banking business. Timely and timely decision-making has become an important guarantee for the survival and development of banks. Only make full use of, to explore their existing data in order to make correct and timely decision-making on the basis of this, to achieve greater efficiency to promote the rapid development of decision information system, realize human unity, to provide effective support for the realization of scientific management and financial information forecast.

The management of commercial banks should draw fund management decision mode of advanced domestic and foreign financial institutions, the establishment of bank decisionmaking group, according to the strategic decision of vane adjustment management in the financial field, leaders and decision makers should timely supplement knowledge, set up think tank research and consultation, the decision-making mechanism, timely service to the board of directors of the bank the scientific decision-making and the full line of business and scientific development, for the construction of "Finance plus financial intelligence wheel drive business model to provide strong support, is committed to continuing to enhance the bank's soft power and influence; through the integration of the whole research strength and external experts, Research on the construction of high level team, build academic exchange platform in the bank". In 2016, China Merchants Bank has a great breakthrough in the innovation, the intelligent customer service upgrade, the introduction of artificial intelligence technology to create a new generation of intelligent service platform, using face and body, voice nuclear intelligent speech processing and human-machine collaboration technology, 
improve service efficiency, optimize service experience, optimize customer structure.

The bank must energetically cultivate innovative talents, actively develop the spirit of innovation and establish a sound innovation mechanism. We will actively promote financial innovation activities such as financial product innovation, financial management innovation and financial service innovation. With innovation, it is better to serve the scientific decision of its own. In 1960s, Citibank's success is the best proof of innovative initiatives, he launched a best of both worlds by tools can be traded in the market freely negotiable certificates of deposit, both for the convenience of the financing of deposit holders, and ensure the benefits of the banks, the result is the enthusiasm greatly stimulated people deposit the first, it brought great influence to the whole banking in the United States, known as "a revolution not have banking". As a reward for Citibank innovation, it has maintained sufficient liquidity and high profitability for a long time.

\section{CONCLUSIONS}

The causes of financial risk of commercial banks are systemically analyzed in the present paper, and the possible causes of financial risk for commercial banks could be the high liabilities rate of assets, a single liabilities structure, high nonperforming assets caused by capital structure imbalance. Therefore, it is necessary for commercial banks to improve the capital structure, to carry out diversified debt service and pay attention to the control of the loan. It is also an urgent task to enhance the risk awareness of the financial personnel and to continue to improve the professional quality of the staff. The adaptation of commercial banks to the macro environment needs the policy of the governments and the efforts of the commercial banks. In addition, strengthening the establishment of internal control system for financial risk and improving the level of scientific and innovative decision-making are also important for commercial banks in the near future. Commercial banks play an important role in the economy development in China. The effective prevention and reduction of financial risks will undoubtedly play an important role in the stability of financial industry. Thus, it is an arduous task to prevent financial risk of commercial banks closely related to our life.

\section{REFERENCES}

[1] Cunningham D F, Rose J T. Bank risk taking and changes in the financial condition of banks' small and midsized commercial customers, 1978-1988 and 1988-1991 [J]. Journal of Financial Services Research, 1994, 8 (4): 301-310.

[2] Anguka W O. The influence of financial risk management on the financial performance of commercial banks in Kenya [J]. University of Nairobi Kenya, 2012,

[3] Amin M A M, Sanusi N A, Kusairi S, et al. Inverse relationship of financial risk and performance in commercial banks in Tanzania [J]. Investment Management \& Financial Innovations, 2014, 11 (4): 279-291.

[4] Kryshtal G. Structure of models for aggregate assessment of financial risk commercial banks [J]. 2016, 1 (178): 11-18.

[5] Li J. Accounting for banks, capital regulation and risk-taking [J]. Journal of Banking \& Finance, 2016, 74 págs. 102-121.

[6] Santomero A M. Commercial bank risk management: An analysis of the process [J]. Journal of Financial Services Research, 1997, 12 (2-3): 83115

[7] Ghosh A. Managing risks in commercial and retail banking [M/OL] 2012

[8] Zhou L, Zhang N, Chen Q. Research on Liquidity Risk and Financial Fragility of Chinese Commercial Banks [J]. Advances in Information Sciences \& Service Sciences, 2012, 4 (22): 787-793.

[9] Hou X, Wang Q, Zhang Q. Market structure, risk taking, and the efficiency of Chinese commercial banks [J]. Emerging Markets Review, 2014, 20 (3): 75-88 